\title{
Hannibal's Pass Once More
}

Author(s): W. A. B. Coolidge

Source: The Geographical Journal, Vol. 13, No. 6 (Jun., 1899), pp. 669-673

Published by: geographicalj

Stable URL: http://www.jstor.org/stable/1774425

Accessed: 27-06-2016 02:35 UTC

\section{Your use of the JSTOR archive indicates your acceptance of the Terms \& Conditions of Use, available at}

http://about.jstor.org/terms

JSTOR is a not-for-profit service that helps scholars, researchers, and students discover, use, and build upon a wide range of content in a trusted digital archive. We use information technology and tools to increase productivity and facilitate new forms of scholarship. For more information about JSTOR, please contact support@jstor.org.

The Royal Geographical Society (with the Institute of British Geographers), Wiley are collaborating with JSTOR to digitize, preserve and extend access to The Geographical Journal 
religions," but only with the facts of faiths, which are elaborated in three sets of chronological tables, with running text and commentary. Necessarily, there " is a mass of learning," but neither "curious," speculative, nor peculiarly my own ; but history, which must be accepted or refuted by the historical method.

Edinburgh, May 2, 1899.

J. G. ForLONG.

\section{The Area of the Philippine Islands.}

In several Government documents the statement is made that the area of the Philippine islands is something over 114,000 square miles. In the latest one just received, it is given as 114,326 square miles. This error has doubtless arisen from a hurried examination of the Spanish documents. We find in the 'Guia Oficial de las Islas Filipinas,' para. 1898 (publicada por la Secretaria del Gobierno General; Manila, 1898), the statement that the archipelago comprises an area of 355,000 square kilometres, without including the Joló (Sulu) group. It then specifies about thirty of the principal islands, and their areas aggregate 298,485 square kilometres, 'That, of course, leaves a multitude of the smaller islands not specified in the guide, but covered by the larger area. The number of square kilometres multiplied by 0.386052 will give the area of the islands specified as 115,238 square miles; and the area of all the islands, less the Joló group, amounts to $137,057 \mathrm{square}$ miles.

Further, the statement is generally made that the archipelago of the Philippines contains from 1000 to 2000 islands, and the 'Guia Oficial' says the number is more than 1200. But, in examining the 'Derrotero del Archiépelago Filipino' (Madrid, 1879), that is, the coast pilot of the Philippines, covering more than 1200 pages, we find that the islas, islitas, isletas, islotes, islotillas, and farallones therein described amount to 583. Of course this does not include reefs, rocks, or hidden dangers.

Geographical Society of the Pacific, San Francisco, Cal.

George Davidson.

\section{Hannibal's Pass once more.}

In his comments on my account of my own belief as to this much-disputed question, Mr. Freshfield repeats many of the arguments formerly urged by him. As I still differ very widely from him, I beg leave to state as concisely as possible the principal reasons for my belief.

First of all, let me say at once that I am quite at one with "Mr. Freshfield in desiderating " historical insight," as well as knowledge of the localities and of the texts. But while I agree that historical insight may so illuminate a number of apparently unconnected historical facts that they at once fall into their proper place, and thus an addition to our previous knowledge is made, I must confess that Mr. Freshfield's use of this "insight" seems to me to come often to no more than plausible guessing in the total absence of authentic facts, one way or the other. If a vacuum is lighted up ever so brilliantly, the vacuum itself is not filled up, but its true nature becomes more evident than ever; and this, $I$ hold, is the case with the history of the Mont Cenis before the eighth century A.D. After this general remark, I proceed to take Mr. Freshfield's arguments in the order in which he has stated them.

1. The first thought that occurs to me as to Mr. Freshfield's explanation of the passage from Varro is this : if all be so clear and simple as Varro's champion urges, how is it that the whole discussion has not been closed long ago? If it is shown that Hannibal cannot have crossed the Mont Genèvre, why is it that very many recent writers conclude that he did cross this pass? Now, we know that the Romans hated and feared the Alps with an energy that astonishes us in modern. 
times, and that their maps of those regions were about as confused and erroneous as possible. Yet we are asked to belizve that one of these Romans deliberately set to work to explore the passes across the Western Alps, and deliberately summed up the results of his journeyings in a few lines, enumerating the names of three generals who had crossed these Alps, but unluckily omitting in just these three cases the names of these passes (or their approximate position), and making the gross error of stating that the "Graian Alps" had formerly been held by the Greeks! Even the most learned writers err sometimes, with the best intentions, and in the most perfect good faith. It was only the other day that a friend of mine, than whom few know more about the Romans, asked me quite seriously whether the Alps could now be crossed at more than three points between the Mediterranean and Mont Blanc, and expressed immense surprise when I replied that I had myself crossed them between those limits by probably 100 or 150 different passes.

There is, too, a further consideration that seems to have escaped the attention of $\mathrm{Mr}$. Freshfield. It is no doubt very tempting to identify the three passes indicated by Varro between the sea and the Little St. Bernard with the three passes in that region now traversed by carriage roads-the Argentière, the Mont Genèvre, and the Mont Cenis. Now, two of these three carriage roads were made by the first Napoleon, and that over the Argentière planned by him, though not completed till quite recently. But I can assert of my own personal experience that within the limits named there are not a few foot or mule passes which are easier and better in every respect than these three carriage passes. None of these generals crossed the Alps summâ diligentia $\hat{a}$, and why should we be tied down to identify these three passes of Varro with the three that for engineering reasons happen now to be provided with carriage roads? Here is a case for " historical insight."

2. Mr. Freshfield admits unreservedly that we possess no direct proof of the early passage of the Mont Cenis from monuments or documents. That is all I have ever maintained-that our present evidence does not allow us to push back the authentic history of this pass beyond the eighth century A.D. Some day, perhaps, a discovery of a charter or monument at present unknown may help us; till then "honest doubt" must prevail. But few, very few, will go with Mr. Freshfield in holding that Cæsar crossed the Mont Cenis; even Napoleon III., in his 'Life of Cæsar,' did not. Further, Mr. Freshfield holds that the Mont Cenis was constantly used as early as the sixth century A.D.- - of which below-adding the absolutely startling assertion, that " by that date" it had "superseded" the Mont Genèvre as the main road between France and Italy!! The only authority that he cites for all this has been already given by him in the Alpine Journal, No. 81,* and now reappears with many fanciful details. Space does not allow me to discuss the latter, and it is needless, for every student of the history of the Maurienne is perfectly well aware that the bishop's see in that valley cannot be dated authentically earlier than the sixth century, while the foundation of Novalesa in 726 simply confirms the ascertained fact that in the eighth century the Mont Cenis was certainly known and traversed.

It will be noticed that Mr. Freshfield sometimes urges that the Mont Cenis itself was crossed in the sixth century A.D., and sometimes merely one of the passes between the Arc valley and the Dora Riparia valley. Now, I am only concerned here to deny this statement so far as regards the Mont Cenis, for it is

* I may be permitted to say that since I wrote my previous note, I have carefully examined in detail the other facts alleged by bim in that article, and they have all broken down. It is only fair to add that Mr. Freshfield collected them from various sources, without apparently himself verifying the references. 
evident, from the sixth-century documents, that some pass was known between the Maurienne and Turin. It may have been the Mont Cenis; it may have been another; we can assert the existence of a pass, but we cannot put a name to it. Now, there are a great number of passes amongst which to make a choice, and all are known personally to me. From St. Jean de Maurienne itself several lead over to the undoubted Roman road over the Col du Lautaret (which joins that over the Mont Genèvre at Briancon), and this road may also be reached by several others starting from St. Michel de Maurienne, a little higher up the Arc valley. Others lead direct from Modane and its neighbourhood to the Dora Riparia valley. Now, most of these are shorter in point of distance than the Mont Cenis, and are also easier. If I were to give reins to my " historical insight," I should select the Col de la Roue, 8419 feet (an extremely easy pass), by which it is possible to go, in about five hours' walking, from Modane (17 miles above St. Jean de Maurienne) to Bardonnèche, which is only 7 miles above Oulx, on the Roman road of the Mont Genèvre.

But, unless some new bit of clear and authentic evidence is produced, I maintain my statement that the Mont Cenis is certainly known only from the eighth century A.D. onwards, though from the sixth century some pass (to which we cannot attach a name) was in use between the Maurienne and Turin.

3. Mr. Freshfield next indulges in some flourishes about documentary evidence not being necessary (despite the purely historical nature of the question!), the genius of the Roman race, the inconceivability of the Mont Cenis not having been known before the eighth century B.c., etc. I venture to pass by this rhetoric with three remarks as to matters of fact. One is that the Roman town of Susa is just as much on the route over the Mont Genèrre as on that over the Mont Cenis. The second is that till the carriage-road was made by Napoleon, the Mont Cenis (especially the descent to Susa) was one of the most difficult and dangerous among the frequented passes over the Alps. The third is that Mr. Freshfield should not commend Simler's sixteenth-century book too warmly, for (despite the natural inclinations of a scholar) he does not breathe a syllable about a Roman road over the Mont Cenis, though devoting nearly a page to the description of the pass; further, the Col de l'Argentière is entirely omitted by Simler, although he repeatedly quotes Paul Jovius' account of the Alps, an account that is actually on the same page of that writer's 'History of his own Times' as his description (the first detailed one we have) of the Argentière à propos of Francis I.'s passage in 1515 !

4. Mr. Freshfield has the advantage over me of having been in the Caucasus. But it is not really necessary to wander so far in search of passes in the mountains locally known and used freely, yet rarely marked on general maps. Let me just cite the names of a few such passes (some of which can only be traversed by mules) between the Argentière and the Little St. Bernard, all crossing the main chain, and all very well known to me-the Col de Mary, the Col de Longet, the Col dell' Agnello, the Col de la Traversette, the Col de la Croix, the Col des Echelles de Planpinet, the Col de la Roue (already mentioned), the Col d'Etache, the Col de l'Autaret, the Col du Mont. Most travellers have never even heard of these passes, but the country people use them almost daily, as well as armies occasionally, and yet they have little, if any, written history.

5. I have not seen Dr. Osiander's treatise, though, as Mr. Freshfield fights shy of him, my ignorance of this book can do no one any harm. But Mr. Freshfield does not mention an even later monograph on the mountain region that we are engaged in studying-Monsieur R. Rey's monograph entitled 'Le Royaume de Cottius et la Province des Alpes Cuttiennes d'Auguste à Dioclétien' (Grenoble, 1898). According to M. Rey (who is well up in the 'Corpus Inscriptionum,' etc., etc.), the valley of the Maurienne above St. Jean de Maurienne formed part of the 
province of the Cottian Alps. Yet, despite his minute discussion of every conceivable point relating to the Romans in this province, including the Roman roads, M. Rey has not a single word to say as to a Roman track across the Mont Cenis (or, indeed, anywhere between the Maurienne and any valley in the direction of Turin), boldly leads both Hannibal and Cæsar across the Mont Genèvre, and recognizes the Argentière as a Roman road by reason of the Roman remains found along this route, though denouncing the inscriptions as forged.

6. I still hold to my definition of the "foot" of a pass, which is quite different from the "foot of the mountains." If Borgo San Dalmazzo is at the Italian "foot" of the Argentière, the French "foot" of that pass must be, not Barcelonnette (as is usually considered to be the case), but somewhere near Lyons, where the road leaves the mountains. Mr. Westlake will not get much help for his Hannibalian theory by placing the "foot" of the Argentière at Borgo San Dalmazzo, for there the route of the Col de Tenda joins that from the Argentière, so that this argument is doubleedged. Similarly, as the routes from the Mont Genèvre and the Mont Cenis join at Susa, any argument as to the length of the plains from the point at which the joint route reaches them to Turin applies to either pass, and not exclusively to one or the other. But this narrow definition of "foot" leads to practical absurdities. According to this theory, the Great St. Bernard pass extends, not from Martigny to Aosta, as is generally believed, but from somewhere near Lyons to Ivrea, while the ice-clad Col du Géant (connecting Chamonix and Courmayeur) must also be taken to extend from near Lyons to Ivrea!

I may note, in passing, that Mr. Freshfield is absolutely mistaken as to Brockedon's use of the expression, "The Pass of the Argentière," for his first words are, "The route from Coni to Embrun, by the Col d'Aıgentière, lies through Borgo San Dalmazzo."

7. I greatly regret that I gave Mr. Freshfield the impression that Fuchs had enumerated every article and work relating to Hannibal's passage; as the tractate is only 152 pages in length, this is clearly impossible. I am sorry that Mr. Freshfield cannot find in Fuchs any reference to that well-worn passage of Varro, but the reason is not far to seek. It is, no doubt, a more serious crime that Fuchs is unaware of Mr. Freshfield's papers on the Argentière in the Alpine Journal (papers also printed in the Proceedings of the R.G.S.; and simply echoed by Prof. Schiller and Mr. W. T. Arnold), but I fear that that periodical (in which many of my writings also are buried) is not very well known outside climbing circles. Mr. Freshfield, too, seems unaware of the fact that the Italian name of the Argentière is the "Colle della Maddalena," the name of "Maddalena" being also given to the great plain that forms the summit-level of the pass. And really, when Mr. Fresbfield states that Mr. Ball and Prof. Bonney (I must plead ignorance as to Sir E. H. Bunbury's Hannibalian views) are opposed to the claims of the Little St. Bernard, he sbould bave added that their views are, as far as I am aware, expressed simply in a résumé of the arguments of Mr. Ellis (in 1854) in favour of the Little Mont Cenis; this résumé was given in the older editions (from 1863 onwards) of the 'Western Alps,' and was (I am proud to relate) erased, root and branch, by me when preparing the new edition (1898) of that work, for its arguments had been refuted in detail by Mr. W. J. Law, in his 'Alps of Hannibal' (1866).

In my humble opinion, the Mont Cenis (big or little) and the Argentière are, with perhaps two or three exceptions, the most "impossible" Hannibalian passes from an historical and a practical point of view. I can therefore easily understand why some writers do not feel called upon to even mention them. And, personally, I should be very sorry if Mr. Freshfield were to incur the fate of the Oxford scholar, who, having edited some classical author, long searched in vain in the pages of 
succeeding editors for any mention of his magnum opus, until one terrible day he found the following brief remark by a stony-hearted German editor, "pessimè Shawius."

8. I cannot believe that Mr. Freshfield is serious in bolding that it is unnecessary to traverse obscure Alpine passes when making Hannibalian researches. Why, then, did he himself (with me in his train) cross the Argentière in June, 1883, and only publish his first article in the following August? I myself wandered for years over Alpine passes south of Mont Blanc without any thought of Hannibal, and so without any prejudice one way or the other. But when my attention was drawn to the Hannibalian question, I had no hesitation in deciding that in my opinion the Mont Genèvre was the only possible pass. And if I ventured to express this opinion and this experience in these pages, it was because I thought and think that practical knowledge was worth as much as book knowledge; for if Mr. Freshfield has crossed the five great passes, I have crossed them too, some more than once, and perhaps 100 or 150 more to the south of Mont Blanc to boot.

9. I cannot conceive how either Mr. Westlake or Mr. Freshfield can find comfort and support from my historical note as to the Argentière. Can either of them quote a case of any authentic traverse of this pass by an army between the time of the Romans and 1515? I fancy they will find some difficulty in doing this; and if they cannot, will they kindly explain why this "most natura. route from Spain to Italy" was unused for 1500 years?

\title{
W. A. B. CoOLIDge.
}

\section{MEETINGS OF THE ROYAL GEOGRAPHICAL SOCIETY, SESSION 1898-1899.}

\author{
Ninth Ordinary Meeting, April 24, 1899.-Sir Clements Markham, \\ K.c.B., President, in the Chair.
}

Elections.-Edward Case, C.E.; Frank James Gray, C.E.; Major Henry W. Wright Guise, 8th Regiment (The King's); Lieut.-Colonel George Rowley Hadaway (late R.A.); Charles Cory Kernick; Vincent T. Murché; Rev. Roland Iaylor-Warren; Richard Glyn Vivian; Rev. Percy St. Michael Podmore, B.A.

The Papers read were :-

(1) "The Nyasa-Tanganyika Plateau." By Captain F. R. F. Boileau, R.E.

(2) "Journeys on the Tanganyika Plateau." By L. A. Wallace.

\section{Tenth Ordinary Meeting, May 8, 1899.-Sir Clements Markham, K.c. B., President, in the Chair.}

Electrons :-Captain F'. R.F. Boileau, R.E. ; Ebenezer Wm. Briggs ; Captain J. E. Brogden (Army Medical Corps); Lieut. Percy A. Clive (Grenadier Guards); John S. Hall; Wm. Holland; William Alfred Johnstone; Captain H. G. Joly de Lotbinière, R.E. ; Commander Alexander McKay; Rev. Ernest Hilton Molesworth, M.A. ; William Llewellyn Preece, M.I.E.E., A.M.Inst.C.E.; Rudolph Wallace Rose; Rev. Haskett Smith, M.A.; James Stuart; Lawrence Aubrey Wallace, A.M.Inst.C.E. ; Colonel Francis Palmer Washington, R.E. (retired); Dr. A. Blair Watson; Walter D. Wilcox, B.A.; Thomas Loxton Woods.

\section{Honorary Corresponding Members.}

H.S.H. the Prince of Monaco; Capitan de Navio Don E. Fernandez Duro; M. Jules Leclerq ; Dr. E. Bretschneider.

No. VI.-June, 1899.] 